Article

\title{
Enhanced Adsorption Capacities of Fungicides Using Peanut Shell Biochar via Successive Chemical Modification with $\mathrm{KMnO}_{4}$ and $\mathrm{KOH}$
}

\author{
Yong-Gu Lee ${ }^{1}{ }^{(D}$, Jaegwan Shin ${ }^{2}$ D, Jinwoo Kwak ${ }^{2}$, Sangwon Kim ${ }^{2}$, Changgil Son ${ }^{2}$, Geon-Youb Kim ${ }^{3}$, \\ Chang-Ha Lee ${ }^{3}$ and Kangmin Chon ${ }^{1,2, * \mathbb{D}}$
}

Citation: Lee, Y.-G.; Shin, J.; Kwak, J.; Kim, S.; Son, C.; Kim, G.-Y.; Lee, C.-H.; Chon, K. Enhanced Adsorption Capacities of Fungicides Using Peanut Shell Biochar via Successive Chemical Modification with $\mathrm{KMnO}_{4}$ and $\mathrm{KOH}$. Separations 2021, 8, 52. https://doi.org/10.3390/ separations 8040052

Academic Editor: Anastasios

Zouboulis, Kangmin Chon and Yong-Gu Lee

Received: 24 March 2021

Accepted: 13 April 2021

Published: 15 April 2021

Publisher's Note: MDPI stays neutral with regard to jurisdictional claims in published maps and institutional affiliations.

Copyright: (c) 2021 by the authors. Licensee MDPI, Basel, Switzerland. This article is an open access article distributed under the terms and conditions of the Creative Commons Attribution (CC BY) license (https:// creativecommons.org/licenses/by/ $4.0 /)$.
1 Department of Environmental Engineering, College of Engineering, Kangwon National University, 1 Kangwondaehak-gil, Chuncheon-si 24341, Korea; yglee19@kangwon.ac.kr

2 Department of Integrated Energy and Infra System, Kangwon National University, 1 Kangwondaehak-gil, Chuncheon-si 24341, Korea; jgshin13@kangwon.ac.kr (J.S.); kh01kjw@kangwon.ac.kr (J.K.); swkim9521@kangwon.ac.kr (S.K.); numer5@kangwon.ac.kr (C.S.)

3 Corporate Collaboration Center, Sungkyunkwan University, 2066, Seobu-ro, Jangan-gu, Suwon-si 16419, Korea; gykim@purivid.com (G.-Y.K.); ha1991@purivid.com (C.-H.L.)

* Correspondence: kmchon@kangwon.ac.kr; Tel.: +82-33-250-6352

\begin{abstract}
This study explored the effects of peanut shell biochar (PSB) on the adsorption capacities of fungicides with and without successive chemical modifications, using $\mathrm{KMnO}_{4}$ and $\mathrm{KOH}\left(\mathrm{PSB}_{\mathrm{OX}-\mathrm{A}}\right.$ ), in order to provide a valuable understanding of their adsorption mechanisms and behaviors. To this end, the physicochemical properties of PSB and PSB $\mathrm{OX}-\mathrm{A}$ were examined by using the BrunauerEmmett-Teller method, Fourier transform infrared spectroscopy, and scanning electron microscopy with an energy dispersive X-ray spectrometer. The effects of temperature, ionic strength, and humic acids on the adsorption of fungicides, using PSB and PSB $_{O X-A}$, were estimated through batch experiments. Furthermore, adsorption kinetics, isotherms, and thermodynamics were studied. The maximum adsorption capacities of fungicides by $\mathrm{PSB}_{\mathrm{OX}-\mathrm{A}}$ were estimated to be more notable $\left(Q_{\max }\right.$ of carbendazim $=531.2 \mu \mathrm{mol} \mathrm{g}{ }^{-1}, Q_{\max }$ of pyrimethanil $=467.7 \mu \mathrm{mol} \mathrm{g}^{-1}$, and $Q_{\max }$ of tebuconazole $\left.=495.1 \mu \mathrm{mol} \mathrm{g}^{-1}\right)$ than PSB $\left(Q_{\max }\right.$ of carbendazim $=92.6 \mu \mathrm{mol} \mathrm{g}^{-1}, Q_{\max }$ of pyrimethanil $=61.7 \mu \mathrm{mol} \mathrm{g}^{-1}$, and $Q_{\max }$ of tebuconazole $=66.7 \mu \mathrm{mol} \mathrm{g}^{-1}$ ). These findings suggest that successive chemical modification using $\mathrm{KMnO}_{4}$ and $\mathrm{KOH}$ could potentially be used to effectively fabricate PSB to remove fungicides in water-treatment processes.
\end{abstract}

Keywords: adsorption; biochar; fungicides; oxidative and alkali modification; peanut shell

\section{Introduction}

Fungicides are chemicals that are used to prevent fungal infections in seeds and plants. Rapid growth in the global population has led to a rise in the demand for crop yields, which has subsequently increased the use of fungicides [1]. This increase can act as a non-point source of pollution in surface water via runoff [2]. Carbendazim (CAR; methyl N-(1H-benzimidazol-2-yl)carbamate), pyrimethanil (PYR; 4,6-dimethyl-Nphenylpyrimidin-2-amine), and tebuconazole (TEB; 1-(4-chlorophenyl)-4,4-dimethyl-3(1,2,4-triazol-1-ylmethyl)pentan-3-ol) have been frequently detected in surface waters $\left(\mathrm{CAR}=0.6-6 \mu \mathrm{g} \mathrm{L}{ }^{-1}, \mathrm{PYR}=4 \mathrm{ng} \mathrm{L}^{-1}\right.$, and TEB $\left.=0.6-200 \mu \mathrm{g} \mathrm{L}^{-1}\right)$ [3-5]. Even though the aforementioned fungicides are generally regarded as having low toxicity, their high chemical stability and slow degradability pose potential risks to aquatic organisms and human health [1]. However, few studies have focused on developing efficient treatments to remove fungicide pollution from water resources [6].

Recently, several researchers have recognized that adsorption is the most efficient treatment option; moreover, its operating cost for fungicide removal in water-treatment plants is low [6]. Activated carbon (AC), a representative adsorbent, is commonly utilized 
in the water-treatment process because it has a large specific surface area, porous structure, and a wide range of $\mathrm{pH}$ reactivity [7]. Moreover, various nanomaterials, including graphene and metal nanoparticles [8] and carbon nanotubes [9], have been used to remove fungicides from water. Zhaokun et al. demonstrated the efficient removal of triazole fungicides on graphene using metal nanoparticles [8]. Chen et al. fabricated magnetic carbon nanotubes for the adsorption of fungicides [9]. Although nanomaterials are beneficial due to their high efficiency and fast adsorption, their physicochemical properties (e.g., small size, persistence, and non-biodegradation) can be detrimental to humans and the environment. Furthermore, the uses of AC and nanomaterials in real-scale water-treatment processes are limited because of their high production and operation costs [10].

In recent years, new developments in waste-reuse technology, such as biochar derived from agricultural and food residues, including peanut shells and ground coffee waste, have become a global focus for research [11,12]. Furthermore, biochar can be a great alternative to AC because of its high specific surface area, porous structure, and various surface functional groups [13]. The adsorption capacity of biochar may be influenced by biomass, carbonization conditions (temperature and retention time), and chemical modification [14]. Chemical modification methods involving oxidative and alkali agents may improve the surface functionality of biochar and enhance electrostatic repulsive interactions with organic pollutants in water [15]. Peanut is a common agricultural residue in the United States. Considerable quantities (about 30 thousand metric tons) of peanuts shell are used to feed and energy resources each year [16]. The main components of peanut shells have been reported to be fiber (60-70 wt.\%), cellulose (34-45 wt.\%), and lignin (27-33 wt.\%). The peanut shells have a cellulose-lignin layer that considerably affects the porous structure and the pyrolysis behavior [17]. In order to make peanut shells an eco-friendly and low-cost alternative adsorbent, they need to be converted into valuable resources. However, most studies have explored the adsorption mechanism by using peanut shell biochar (PSB) of heavy metals, such as $\mathrm{Ni}(\mathrm{II}), \mathrm{Cd}(\mathrm{II}), \mathrm{Cu}$ (II), $\mathrm{Pb}$ (II), and $\mathrm{Zn}(\mathrm{II})[16,18]$. Moreover, there is a need for a comprehensive study on the effects of successive chemical modification of PSB with potassium permanganate $\left(\mathrm{KMnO}_{4}\right)$ and potassium hydroxide $(\mathrm{KOH})$ on the adsorption behavior of fungicides.

This study investigated the adsorption behaviors of fungicides by PSB and successive $\mathrm{KMnO}_{4}$ and $\mathrm{KOH}$ modified PSB ( $\mathrm{PSB}_{\mathrm{OX}-\mathrm{A}}$ ) to compare the physicochemical properties of PSB and $\mathrm{PSB}_{\mathrm{OX}-\mathrm{A}}$ (surface morphology, porous structure, bulk elemental composition, and surface functional groups). The adsorption behavior of fungicides (i.e., CAR, PYR, and TEB) by PSB and PSB Ox-A was optimized and evaluated through batch experiments. The adsorption kinetics, isotherms, and thermodynamics were used to identify the primary adsorption mechanisms of CAR, PYR, and TEB, using PSB and PSB ${ }_{O X}$-A Furthermore, the effects of temperature, ionic strength, and humic acids (HA) on the adsorption of CAR, PYR, and TEB by PSB and PSB $O$ XX-A were examined.

\section{Materials and Methods}

\subsection{Chemicals}

All chemicals and fungicides were of analytical grade. CAR (methyl N-(1H-benzimidazol2-yl)carbamate), PYR (4,6-dimethyl- $\mathrm{N}$-phenylpyrimidin-2-amine), TEB (1-(4-chlorophenyl)4,4-dimethyl-3-(1,2,4-triazol-1-ylmethyl)pentan-3-ol), $\mathrm{KMnO}_{4}, \mathrm{KOH}$, sodium hydroxide $(\mathrm{NaOH})$, hydrochloric acid $(\mathrm{HCl})$, sodium chloride $(\mathrm{NaCl})$, and $\mathrm{HA}$ were purchased from Sigma-Aldrich (St. Louis, MO, USA). High-performance liquid chromatography (HPLC)grade acetonitrile (ACN) was obtained from J.T. Baker (Deventer, Netherlands), and phosphoric acid $\left(\mathrm{H}_{3} \mathrm{PO}_{4}\right)$ was purchased from FUJIFILM Wako Pure Chemical Corporation (Osaka, Japan). The use of ACN is due to its strong solvation properties for a wide range of polar and nonpolar organic solutes and advantageous properties, including low viscosity and low toxicity [19]. A mixed stock solution containing CAR, PYR, and TEB (concentration of each fungicide $=1 \mathrm{mmol} \mathrm{L}^{-1}$ ) was prepared by using ACN and deionized (DI) water $(50: 50, v / v)$. DI water was produced by using a Nanopure Water System (electrical 
resistivity $>18.2 \mathrm{M} \Omega \mathrm{cm}^{-1}$; Barnstead, Lake Balboa, CA, USA), and it was used to make the samples. These stock solutions were stored at $4{ }^{\circ} \mathrm{C}$, in the dark, prior to use. The physicochemical properties of CAR, PYR, and TEB are summarized in Table 1.

Table 1. Physicochemical properties of the selected fungicides.

\begin{tabular}{|c|c|c|c|c|c|c|c|c|c|c|c|}
\hline \multirow{2}{*}{$\begin{array}{l}\text { Compounds } \\
\text { (Abbreviation) }\end{array}$} & \multirow[b]{2}{*}{ Formula } & \multirow[b]{2}{*}{ Structure } & \multirow{2}{*}{$\begin{array}{l}\text { Molecular } \\
\text { Weight } \\
\left(\mathrm{g} \mathrm{mol}^{-1}\right)\end{array}$} & \multicolumn{3}{|c|}{ Charge $^{a}$} & \multicolumn{3}{|c|}{$\log D^{a}$} & \multirow[b]{2}{*}{$\mathrm{p} K_{\mathrm{a}}{ }^{\mathrm{a}}$} & \multirow{2}{*}{$\begin{array}{l}\text { Solubility } \\
\text { in Water } \\
\left(\mathrm{g} \mathrm{L}^{-1}, \mathrm{pH} 7\right)\end{array}$} \\
\hline & & & & $\begin{array}{l}\mathrm{pH} \\
3.0\end{array}$ & $\begin{array}{l}\mathrm{pH} \\
7.0\end{array}$ & $\begin{array}{l}\text { pH } \\
11.0\end{array}$ & $\begin{array}{l}\mathrm{pH} \\
3.0\end{array}$ & $\begin{array}{l}\mathrm{pH} \\
7.0\end{array}$ & $\begin{array}{c}\mathrm{pH} \\
11.0\end{array}$ & & \\
\hline $\begin{array}{l}\text { Carbendazim } \\
\text { (CAR) }\end{array}$ & $\mathrm{C}_{9} \mathrm{H}_{9} \mathrm{~N}_{3} \mathrm{O}_{2}$ & & 191.19 & 1 & 0 & -1 & 0.73 & 1.80 & 1.01 & 4.28 & 0.008 \\
\hline $\begin{array}{l}\text { Pyrimethanil } \\
\text { (PYR) }\end{array}$ & $\mathrm{C}_{12} \mathrm{H}_{13} \mathrm{~N}_{3}$ & & 199.25 & 1 & 0 & 0 & 1.87 & 2.43 & 2.43 & 3.44 & 0.121 \\
\hline $\begin{array}{l}\text { Tebuconazole } \\
\text { (TEB) }\end{array}$ & $\mathrm{C}_{16} \mathrm{H}_{22} \mathrm{ClN}_{3} \mathrm{O}$ & & 307.82 & 0 & 0 & 0 & 3.65 & 3.69 & 3.69 & 2.01 & 0.036 \\
\hline
\end{tabular}

${ }^{a}$ ChemAxon (http:/ / www.chemicalize.org, 2 January 2021). ${ }^{\mathrm{b}}$ Hazardous Substances Data Bank (http:/ / pubchem.ncbi.nih.gov, 2 January 2021).

\subsection{Preparation of $P S B$ and $P S B_{O X-A}$}

The detailed preparation method of the PSB via successive chemical modification with $\mathrm{KMnO}_{4}$ and $\mathrm{KOH}$ was modified in a previous study [20].

\subsubsection{PSB}

Peanut shells were purchased from a local grocery store in Chuncheon-si (Gangwondo, Korea). They were rinsed several times with DI water and dried in an oven for $24 \mathrm{~h}$, at $105^{\circ} \mathrm{C}$. The PSB was pyrolyzed by using a tubular furnace (PyroTech, Namyangju-si, Korea) for $2 \mathrm{~h}$, at $700{ }^{\circ} \mathrm{C}$, under $\mathrm{N}_{2}$ atmosphere (heating rate $=10^{\circ} \mathrm{C} \mathrm{min}^{-1}$; the $\mathrm{N}_{2}$ flow rate $=0.25 \mathrm{~L} \mathrm{~min}^{-1}$ ). After the entire procedure was completed, the produced PSB was rinsed with DI water and dried in an oven at $105^{\circ} \mathrm{C}$, for $12 \mathrm{~h}$.

\subsection{2. $\mathrm{PSB}_{\mathrm{OX}-\mathrm{A}}$}

To enhance the surface functionality of PSB, the PSB $(5 \mathrm{~g})$ produced was mixed with $0.5 \% \mathrm{KMnO}_{4}(10 \mathrm{~mL})$ by stirring at $20 \pm 0.5^{\circ} \mathrm{C}$ for $4 \mathrm{~h}$ and drying in an oven, at $60{ }^{\circ} \mathrm{C}$, for $4 \mathrm{~h}$. The modified PSB with $\mathrm{KMnO}_{4}$ was pyrolyzed by using a tubular furnace at $700{ }^{\circ} \mathrm{C}$, for $2 \mathrm{~h}$, under $\mathrm{N}_{2}$ atmosphere (heating rate $=10^{\circ} \mathrm{C} \mathrm{min}^{-1}$; $\mathrm{N}_{2}$ flow rate $=0.25 \mathrm{~L} \mathrm{~min}^{-1}$ ). The modified PSB with $\mathrm{KMnO}_{4}$ was rinsed with DI water several times and dried in an oven, at $105^{\circ} \mathrm{C}$, for $12 \mathrm{~h}$. Furthermore, the modified PSB with $\mathrm{KMnO}_{4}$ was added to $\mathrm{KOH}$ $(15 \mathrm{~g})$ and pyrolyzed in a tubular furnace, at $700{ }^{\circ} \mathrm{C}$ (heating rate $=10^{\circ} \mathrm{C} \mathrm{min}{ }^{-1}$ ), for $1 \mathrm{~h}$, under $\mathrm{N}_{2}$ atmosphere (flow rate $=0.25 \mathrm{~L} \mathrm{~min}^{-1}$ ). The $\mathrm{PSB}_{\mathrm{OX} \text {-A }}$ produced was rinsed with DI water several times and dried in an oven, at $60^{\circ} \mathrm{C}$, for $24 \mathrm{~h}$. The dried PSB $\mathrm{OX}$-A was passed through a 100-mesh sieve, to maintain a uniform size, after which it was stored in a desiccator prior to analysis.

\subsection{Characteristics of PSB and PSBOX-A}

\subsubsection{Specific Surface Area and Porosity}

The specific surface areas $\left(\mathrm{m}^{2} \mathrm{~g}^{-1}\right)$ of PSB and PSB $\mathrm{OX}$-A were determined by using the Brunauer-Emmett-Teller (BET) method on the $\mathrm{N}_{2}$ adsorption-desorption isotherms 
at 77.3 $\mathrm{K}$ in the relative pressure range of 0.01-0.99 (ASAP 2020 Plus, Micromeritics, GA, USA). The total pore volume $\left(\mathrm{cm}^{3} \mathrm{~g}^{-1}\right)$ and average pore size $(\mathrm{nm})$ were calculated by using the Barrett-Joyner-Halenda (BJH) method [21].

\subsubsection{Elemental Compositions}

The elemental compositions (i.e., carbon $(\mathrm{C})$, hydrogen $(\mathrm{H})$, oxygen $(\mathrm{O})$, nitrogen $(\mathrm{N})$, and sulfur (S)) of PSB and PSB $\mathrm{Ox}$-A were measured by using a EuroEA3000 elemental analyzer (EuroVector S.p.A, Via F.lli Cuzio, Italy). Ash content was calculated by subtracting the $\mathrm{C}, \mathrm{H}, \mathrm{O}, \mathrm{N}$, and $\mathrm{S}$ contents from the total amount of PSB and $\mathrm{PSB}_{\mathrm{OX}-\mathrm{A}}$. The atomic molar ratios of $\mathrm{H} / \mathrm{C}$ and $\mathrm{O} / \mathrm{C}+\mathrm{N} / \mathrm{C}$ were used to reveal the aromaticity and polarity of $\mathrm{PSB}$ and $\mathrm{PSB}_{\mathrm{OX}-\mathrm{A}}$, respectively [21].

\subsubsection{Scanning Electron Microscopy Analysis}

The surface morphologies of PSB and $\mathrm{PSB}_{\mathrm{OX}-\mathrm{A}}$ were identified by using an S-4800 scanning electron microscope (SEM; Hitachi, Tokyo, Japan) with an energy dispersive X-ray (EDX) spectrometer.

\subsubsection{Fourier Transform Infrared Spectroscopy Analysis}

Fourier transform infrared (FTIR) spectroscopy with a $\mathrm{KBr}$ pellet was used to qualitatively analyze the surface functional groups of PSB and $\mathrm{PSB}_{\mathrm{OX}-\mathrm{A}}$ ranging between 400 and $4000 \mathrm{~cm}^{-1}$ (Vertex 70, Bruker, Billerica, MA, USA).

\subsection{Analytical Methods}

The concentrations of CAR, PYR, and TEB in the samples were measured by using HPLC coupled with a column (XDB C18; ZORBAX Eclipse ${ }^{\circledR}, 4.6 \mathrm{~mm} \times 150 \mathrm{~mm}$, inner diameter $=5 \mu \mathrm{m}$; Agilent, Santa Clara, CA, USA) and a UVA detector (SPD-10AVP, Shimadzu, Kyoto, Japan) at $210 \mathrm{~nm}$. The mobile phase (CAN: $\left.0.05 \mathrm{M} \mathrm{H}_{3} \mathrm{PO}_{4}(50: 50, v / v)\right)$ was operated under isocratic conditions (flow rate $=1.0 \mathrm{~mL} \mathrm{~min}^{-1}$ ) for $15 \mathrm{~min}$. Various sample conditions were used to evaluate the effects of temperature, ionic strength, and HA on the adsorption of CAR, PYR, and TEB when using PSB and PSB $\mathrm{OX}-\mathrm{A}$ (the concentration of each fungicide $=10 \mu \mathrm{mol} \mathrm{L}^{-1}$, temperature $=15-35^{\circ} \mathrm{C}$, concentrations of $\mathrm{NaCl}=0-0.1 \mathrm{M}$, and concentration of $\left.\mathrm{HA}=5 \mathrm{mg} \mathrm{L}^{-1}\right)$. All adsorption experiments were conducted in triplicate, using a shaking incubator (Vision Scientific, Daejeon, Korea). Then, the sample solutions were filtered by using a nominal pore size of $0.7 \mu \mathrm{m}$ glass fiber filter (GF/F; Whatman, Maidstone, UK) to eliminate PSB and PSB $\mathrm{OX}$-A.

The amounts of CAR, PYR, and TEB adsorbed per unit mass of PSB and PSB $\mathrm{OX}_{\mathrm{A}-\mathrm{A}}$ at equilibrium, $Q_{e}\left(\mu \mathrm{mol} \mathrm{g}{ }^{-1}\right)$, and removal efficiencies (\%) of CAR, PYR, and TEM by PSB and $\mathrm{PSB}_{\mathrm{OX}-\mathrm{A}}$ were calculated by using the following equations:

$$
\begin{aligned}
& \qquad Q_{e}=\frac{\left(C_{0}-C_{e}\right) V}{M}, \\
& \text { Removal efficiency of fungicide }(\%)=\frac{C_{0}-C_{e}}{C_{0}} \times 100,
\end{aligned}
$$

where $C_{0}$ and $C_{\mathrm{e}}\left(\mu \mathrm{mol} \mathrm{L}{ }^{-1}\right)$ are the initial and equilibrium concentrations of CAR, PYR, and TEB, respectively. $V(\mathrm{~L})$ is the sample solution volume, and $M(\mathrm{~g})$ is the amount of PSB and $\mathrm{PSB}_{\mathrm{OX}-\mathrm{A}}$.

The adsorption kinetics of CAR, PYR, and TEB were examined by using the pseudofirst-order (Equation (3)) and pseudo-second-order (Equation (4)) kinetic models (adsorbent dosage $=50 \mathrm{mg} \mathrm{L}^{-1}$, initial concentration of each fungicide $=10 \mu \mathrm{mol} \mathrm{L}^{-1}$, contact time $=$ $0-24 \mathrm{~h}$, agitation speed $=150 \mathrm{rpm}$, temperature $=25^{\circ} \mathrm{C}$, and $\mathrm{pH}=7.0$ ) [22]:

$$
Q_{t}=Q_{e}\left(1-\frac{1}{\exp \left(k_{1} t\right)}\right.
$$




$$
Q_{t}=Q_{e}\left(1-\frac{1}{1+Q_{e} k_{2} t}\right),
$$

where $Q_{t}\left(\mu \mathrm{mol} \mathrm{g}^{-1}\right)$ is the amount of adsorbed CAR, PYR, and TEB on PSB and PSB $O$-A at adsorption time $t(\mathrm{~h})$. Moreover, $k_{1}(1 / \mathrm{h})$ and $k_{2}\left(\mathrm{~g} \mu \mathrm{mol}^{-1} \cdot \mathrm{h}\right)$ are the rate constants of the pseudo-first-order and pseudo-second-order models, respectively.

The adsorption isotherms of CAR, PYR, and TEB were investigated at five different initial concentrations $\left(10,20,30,40\right.$, and $\left.50 \mu \mathrm{mol} \mathrm{L}^{-1}\right)$, under fixed conditions (adsorbent dosage $=50 \mathrm{mg} \mathrm{L}^{-1}$, contact time $=24 \mathrm{~h}$, agitation speed $=150 \mathrm{rpm}$, temperature $=25^{\circ} \mathrm{C}$, and $\mathrm{pH}=7.0)[23]$.

$$
\begin{aligned}
& \text { Langmuir Isotherm: } Q_{e}=\frac{Q_{\max } K_{L} C_{e}}{1+K_{L} C_{e}}, \\
& \text { Freundlich isotherm: } Q_{e}=K_{F} C_{e}^{1 / n},
\end{aligned}
$$

where $Q_{\max }\left(\mu \mathrm{mol} \mathrm{g}{ }^{-1}\right)$ is the maximum adsorption capacity in the Langmuir isotherm

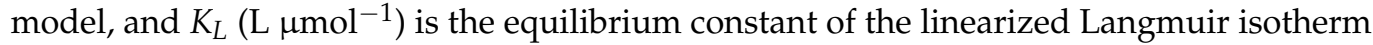
model. $R_{L}=1 /\left(1+K_{L} C_{0}\right)$, derived from $K_{L}$, is used to compare the adsorption affinity of the Langmuir isotherms. $K_{F}\left(\mu \mathrm{mol}^{1-1 / \mathrm{n}} \mathrm{L}^{1 / \mathrm{n}} \mathrm{g}^{-1}\right)$ and $n$ (dimensionless) are constants associated with the relative maximum adsorption capacity and adsorption intensity, respectively [24].

The thermodynamic parameters of CAR, PYR, and TEB adsorption were estimated by using Equations (7)-(9) [25].

$$
\begin{gathered}
K_{d}=\frac{Q_{e}}{C_{e}}, \\
\Delta G^{\circ}=-R T \ln \left(1000 K_{d}\right), \\
\ln \left(1000 K_{d}\right)=-\frac{\Delta H^{\circ}}{R T}+\frac{\Delta S^{\circ}}{R},
\end{gathered}
$$

where $K_{d}\left(\mathrm{~L} \mathrm{~g}^{-1}\right)$ is the partition coefficient; $\Delta G^{\circ}$ in $\left(\mathrm{kJ} \mathrm{mol}^{-1}\right), \Delta H^{\circ}$ in $\left(\mathrm{kJ} \mathrm{mol}^{-1}\right)$, and $\Delta S^{\circ}$ $\left(\mathrm{J} \mathrm{mol}^{-1} \cdot \mathrm{K}\right)$ are the Gibbs free energy, enthalpy, and entropy, respectively. $R\left(\mathrm{~J} \mathrm{~mol}^{-1} \cdot \mathrm{K}\right)$ and $T(\mathrm{~K})$ are the ideal gas constant $\left(8.314 \mathrm{~J} \mathrm{~mol}^{-1} \cdot \mathrm{K}\right)$ and the absolute temperature of the sample solutions. $\Delta H^{\circ}$ and $\Delta S^{\circ}$ were calculated as the slope and intercept in the linear graph of $\ln \left(K_{d}\right)$ and $1 / T$, respectively.

\section{Results and Discussion}

\subsection{Physicochemical Properties of PSB and PSBOX-A}

The physicochemical properties (e.g., bulk element and ash contents, the atomic molar ratio, specific surface area, total pore volume, average pore size, and BET isotherms) associated with the adsorption capacity of PSB and PSB $\mathrm{OX}-\mathrm{A}$ are presented in Figure 1 and Table 2. The bulk element and ash contents of PSB $(\mathrm{C}=86.6 \%, \mathrm{H}=1.6 \%, \mathrm{O}=3.7 \%$, $\mathrm{N}=1.7 \%, \mathrm{~S}=0.1 \%$, and $\mathrm{ash}=6.3 \%)$ and $\mathrm{PSB}_{\mathrm{OX}-\mathrm{A}}(\mathrm{C}=82.1 \%, \mathrm{H}=1.1 \%, \mathrm{O}=4.9 \%, \mathrm{~N}=1.3 \%$, $\mathrm{S}=0.2 \%$, and ash $=10.5 \%$ ) have revealed considerable differences due to the successive $\mathrm{KMnO}_{4}$ and $\mathrm{KOH}$ modification processes. Furthermore, $\mathrm{PSB}_{\mathrm{OX}}$-A presented lower atomic molar ratios of $\mathrm{H} / \mathrm{C}(0.16)$ than that of PSB (0.23), but the sum of $\mathrm{O} / \mathrm{C}$ and $\mathrm{N} / \mathrm{C}$ values for $\mathrm{PSB}_{\mathrm{OX}-\mathrm{A}}(0.05)$ were similar to those of PSB (0.05). These findings indicate that PSB $\mathrm{OX}_{-\mathrm{A}}$ has a higher aromaticity $\left(\mathrm{H} / \mathrm{C}\right.$ value: $\left.\mathrm{PSB}>\mathrm{PSB}_{\mathrm{OX}-\mathrm{A}}\right)$ than PSB [26]. Additionally, PSB $\mathrm{OX}-\mathrm{A}$ had a higher specific surface area and total pore volume than that of PSB, but the average pore size of PSB OX-A was smaller than that of PSB. The specific surface area $\left(1977.6 \mathrm{~m}^{2} \mathrm{~g}^{-1}\right)$ and total pore volume $\left(0.12 \mathrm{~cm}^{3} \mathrm{~g}^{-1}\right)$ of $\mathrm{PSB}_{\mathrm{OX}-\mathrm{A}}$ were significantly greater than those of PSB (specific surface area $=93.9 \mathrm{~m}^{2} \mathrm{~g}^{-1}$ and total pore volume $=0.04 \mathrm{~cm}^{3} \mathrm{~g}^{-1}$ ), given that the porous structures were changed by the successive chemical modification using $\mathrm{KMnO}_{4}$ and $\mathrm{KOH}$ [11]. However, the average pore size of $\mathrm{PSB}_{\mathrm{OX}-\mathrm{A}}(3.4 \mathrm{~nm})$ was not significantly different from that of PSB $(3.8 \mathrm{~nm})$. Therefore, the CAR, PYR, and TEB adsorption capacities of $\mathrm{PSB}_{\mathrm{OX}-\mathrm{A}}$ were expected to be enhanced compared with those of PSB. 


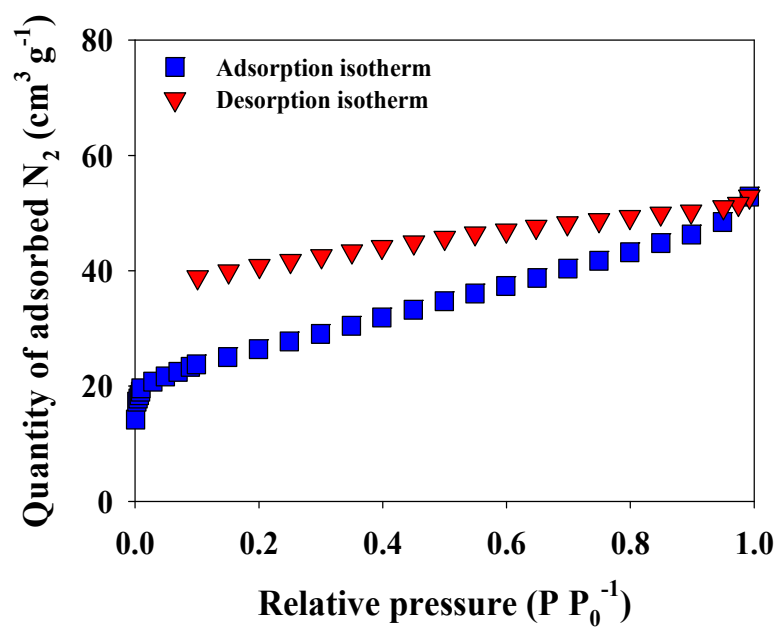

(a)

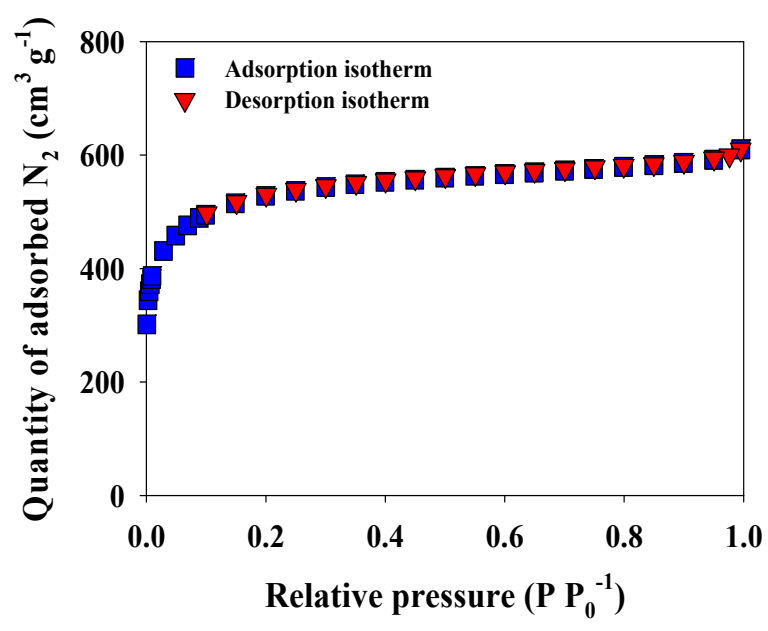

(b)

Figure 1. $\mathrm{N}_{2}$ adsorption-desorption isotherm curves of the (a) peanut shell biochar (PSB) and (b) $\mathrm{KMnO}_{4}$ and $\mathrm{KOH}_{\text {modified }}$ PSB (PSB $\mathrm{OX}-\mathrm{A})$.

Table 2. Physicochemical characteristics of PSB and $\mathrm{PSB}_{\mathrm{OX}-\mathrm{A}}$.

\begin{tabular}{cccc}
\hline & Properties & PSB & PSB $_{\text {OX-A }}$ \\
\hline & $\mathrm{C}$ & 86.6 & 82.1 \\
& $\mathrm{H}$ & 1.6 & 1.1 \\
Bulk elemental & $\mathrm{O}$ & 3.7 & 4.9 \\
constitution $(\%)$ & $\mathrm{N}$ & 1.7 & 1.3 \\
& $\mathrm{~S}$ & 0.1 & 0.2 \\
& $\mathrm{Ash}$ & 6.3 & 10.5 \\
\hline & $\mathrm{H} / \mathrm{C}$ & 0.2 & 0.1 \\
Atomic ratio & $\mathrm{O} / \mathrm{C}$ & 0.03 & 0.04 \\
& $\mathrm{~N} / \mathrm{C}$ & 0.02 & 0.01 \\
\hline Specific surface area $\left(\mathrm{m}^{2} \mathrm{~g}^{-1}\right)$ & 93.9 & 1977.6 \\
Total pore volume $\left(\mathrm{cm}^{3} \mathrm{~g}^{-1}\right)$ & 0.04 & 0.12 \\
Average pore size $\left(\mathrm{nm}^{-1}\right.$ & 3.8 & 3.4 \\
\hline
\end{tabular}

The SEM images of PSB and PSB ${ }_{O X-A}$ are shown in Figure 2. The surface of PSB is smooth and flat, but $\mathrm{PSB}_{\mathrm{OX}-\mathrm{A}}$ has porous and uneven structures. These results indicate that chemical modification using $\mathrm{KMnO}_{4}$ and $\mathrm{KOH}$ might change the surface morphology of the PSB with respect to the adsorption of fungicides [27]. The SEM-EDX results of PSB and $\mathrm{PSB}_{\mathrm{OX}-\mathrm{A}}$ demonstrated the effect of chemical modification with $\mathrm{KMnO}_{4}$ and $\mathrm{KOH}$ on the differences in the constituents of PSB and $\mathrm{PSB}_{\mathrm{OX}-\mathrm{A}}$. The $\mathrm{PSB}_{\mathrm{OX}-\mathrm{A}}$ was composed of C $(82.05 \%), \mathrm{O}(17.62 \%), \mathrm{K}(0.19 \%)$, and Mn $(0.14 \%)$. However, PSB only consisted of C $(85.58 \%)$ and $\mathrm{O}(14.42 \%)$. The presence of $\mathrm{K}$ and $\mathrm{Mn}$ atoms in $\mathrm{PSB}_{\mathrm{OX}-\mathrm{A}}$ could explain why $\mathrm{K}$ and Mn were combined on the surface of PSB during the successive chemical modification using $\mathrm{KMnO}_{4}$ and $\mathrm{KOH}$. 


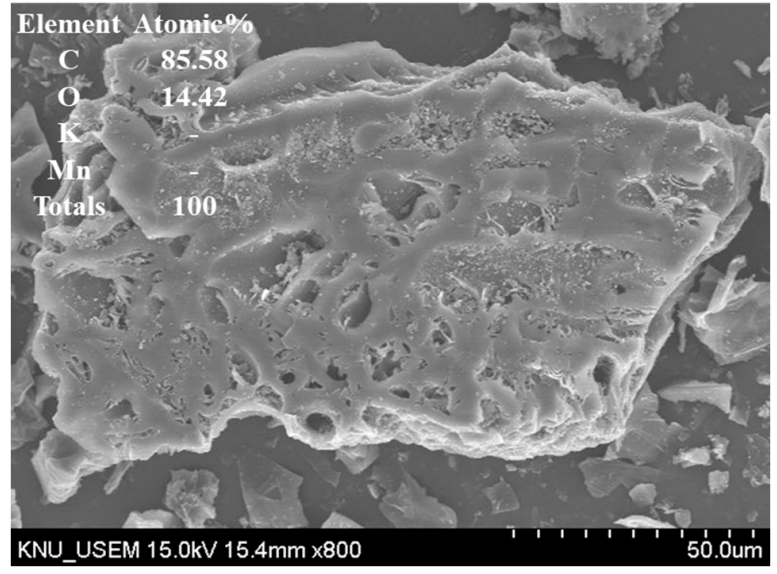

(a)

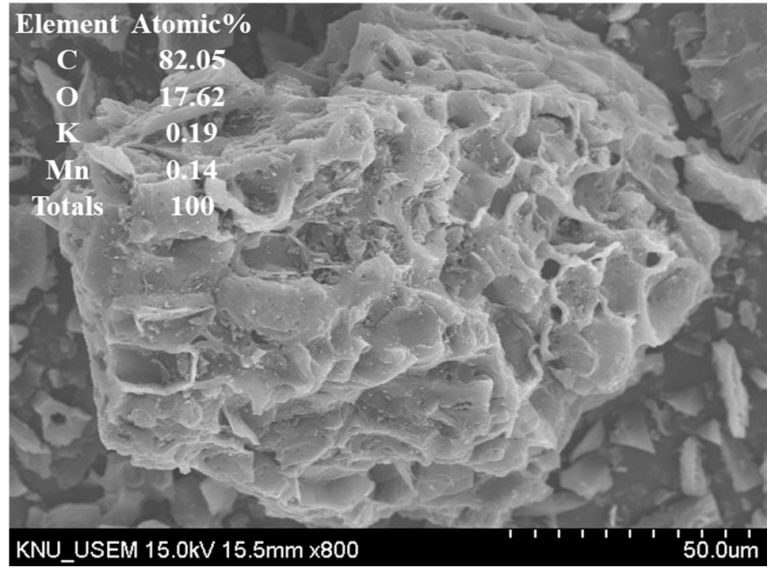

(b)

Figure 2. Scanning electron microscopy (SEM) images of (a) peanut shell biochar (PSB) and (b) $\mathrm{KMnO}_{4}$ and $\mathrm{KOH}$ modified PSB $\left(\right.$ PSB $\left._{\mathrm{OX}-\mathrm{A}}\right)$ (magnification $\left.\times 800\right)$.

Figure 3 shows the FTIR spectra of PSB and PSB ${ }_{\text {OX-A }}$. The IR peak at $3420 \mathrm{~cm}^{-1}$ indicates the O-H groups of alcohols [14]. The IR peaks at 1570 and $1180 \mathrm{~cm}^{-1}$ could be attributed to the vibrations of the $\mathrm{C}=\mathrm{C}$ stretching of aromatic groups and the $\mathrm{C}-\mathrm{O}$ stretching of phenolic and carboxylic groups, respectively $[28,29]$. The intensities of the IR peaks (i.e., $\mathrm{OH}$ alcohol groups, $\mathrm{C}=\mathrm{C}$ aromatic groups, and $\mathrm{C}-\mathrm{O}$ phenolic and carboxylic groups) for $\mathrm{PSB}_{\mathrm{OX}-\mathrm{A}}$ were significantly higher than those of PSB. These observations suggest that the differences in the adsorption capacities of PSB and PSB $_{O X-A}$ could influence the adsorption of fungicides because of the successive chemical modifications with $\mathrm{KMnO}_{4}$ and $\mathrm{KOH}$.

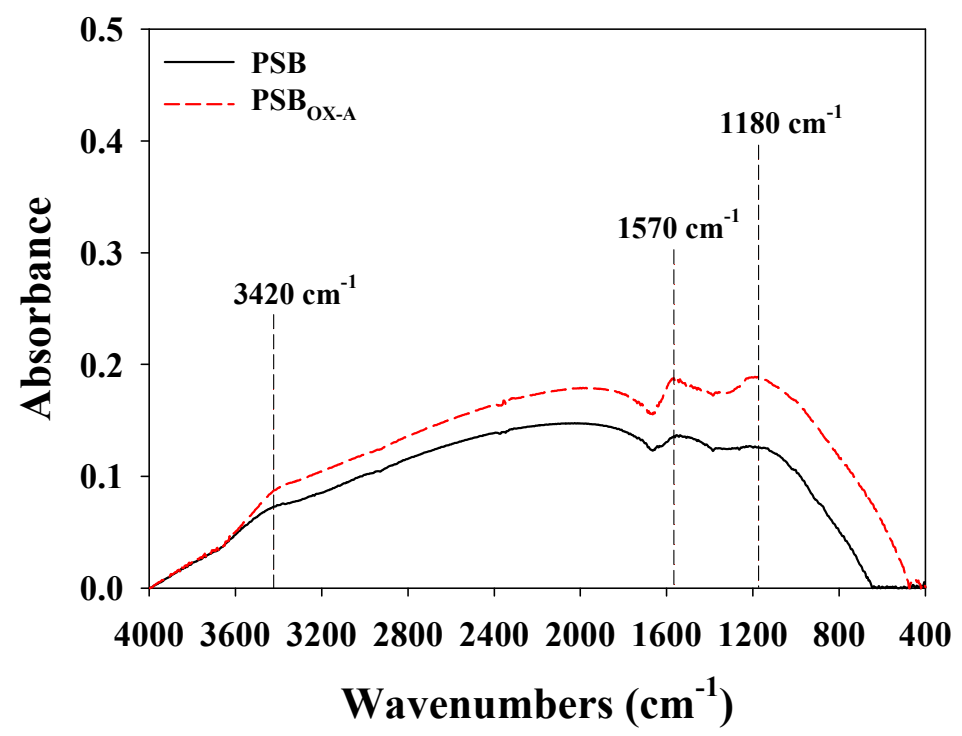

Figure 3. Fourier-transform infrared (FTIR) spectra of PSB and PSB $\mathrm{OX}-\mathrm{A}$.

\subsection{Effects of Absorbent Dosages}

The effects of PSB and PSB $\mathrm{OX}_{-\mathrm{A}}$ dosages on the removal efficiencies of CAR, PYR, and TEB are shown in Figure 4. The adsorption capacities of CAR, PYR, and TEB using PSB and $\mathrm{PSB}_{\mathrm{OX}-\mathrm{A}}$ continuously decreased, and the removal efficiency of fungicides on PSB and $\mathrm{PSB}_{\mathrm{OX}-\mathrm{A}}$ gradually increased. This is because, when the initial concentrations of CAR, PYR, and TEB are fixed, the adsorption capacity per unit of the adsorbents tends to decline as the

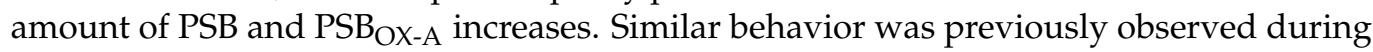
the removal of the fungicides (e.g., triclosan and triclocarban) using Zr-based magnetic metal-organic frameworks [30]. Based on these experiments on the removal efficiency of 
CAR, PYR, and TEB according to the PSB and PSB $\mathrm{OX}$-A dosages, $50 \mathrm{mg} \mathrm{L}^{-1}$ was selected as the optimal dosage and applied to the subsequent experiments.

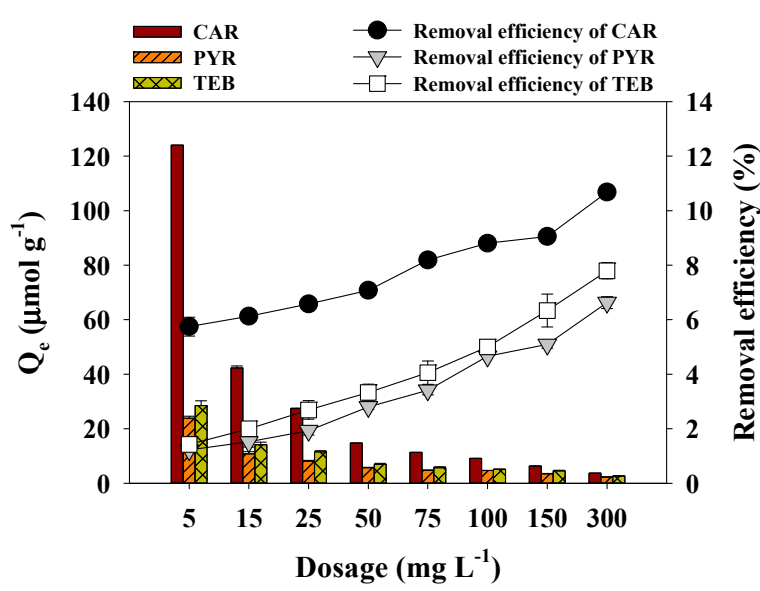

(a)

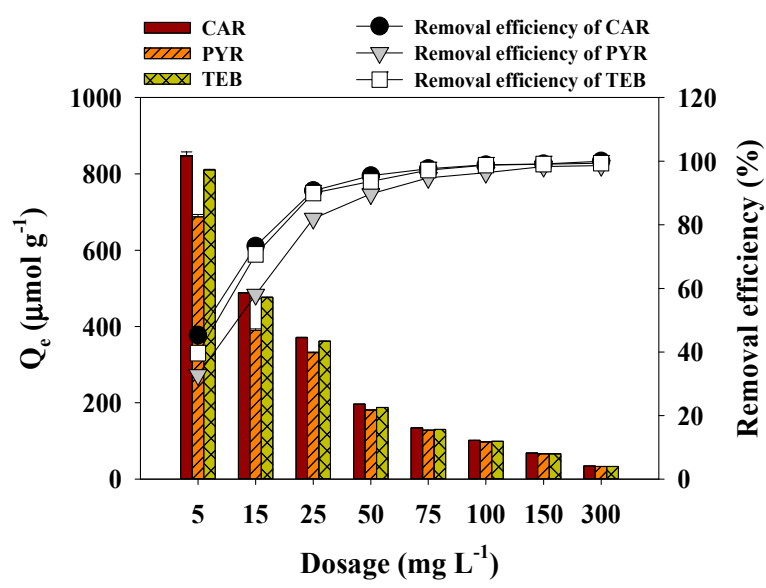

(b)

Figure 4. Effects of adsorbent dosages on the removal efficiency of CAR, PYR, and TEB by (a) PSB and (b) PSB $\mathrm{OX}_{-\mathrm{A}}$ (agitation speed $=150 \mathrm{rpm}$; initial concentration of each fungicide $=10 \mu \mathrm{M}$; contact time $=24 \mathrm{~h}$; temperature $=25^{\circ} \mathrm{C} ; \mathrm{pH}=7.0$ ).

\subsection{Adsorption Kinetics of Fungicides}

Figure 5 shows the adsorption kinetics of CAR, PYR, and TEB when using PSB and $\mathrm{PSB}_{\mathrm{OX}-\mathrm{A}}$. The fast adsorption reaction was completed within $4 \mathrm{~h}$ for fungicides on the

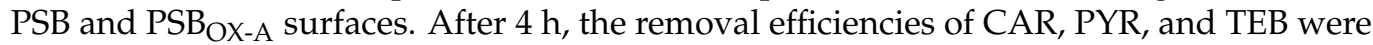
increased by PSB and $\mathrm{PSB}_{\mathrm{OX}-\mathrm{A}}$ because the activated binding sites on PSB and $\mathrm{PSB}_{\mathrm{OX}-\mathrm{A}}$ surfaces were saturated [12]. The removal efficiencies of CAR, PYR, and TEB by PSB (removal efficiency of CAR $=7.3 \pm 0.04 \%$, removal efficiency of PYR $=3.1 \pm 0.04 \%$, and removal efficiency of TEB $=5.8 \pm 0.08 \%$ ) were considerably lower than those of CAR,

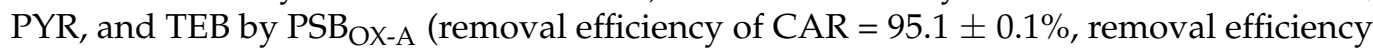
of PYR $=89.9 \pm 0.02 \%$, and removal efficiency of TEB $=92.7 \pm 0.1 \%$ ). These observations were attributed to the differences in the physicochemical properties (i.e., specific surface area, total pore volume, and surface functional groups) of PSB and $\mathrm{PSB}_{\mathrm{OX}-\mathrm{A}}$.

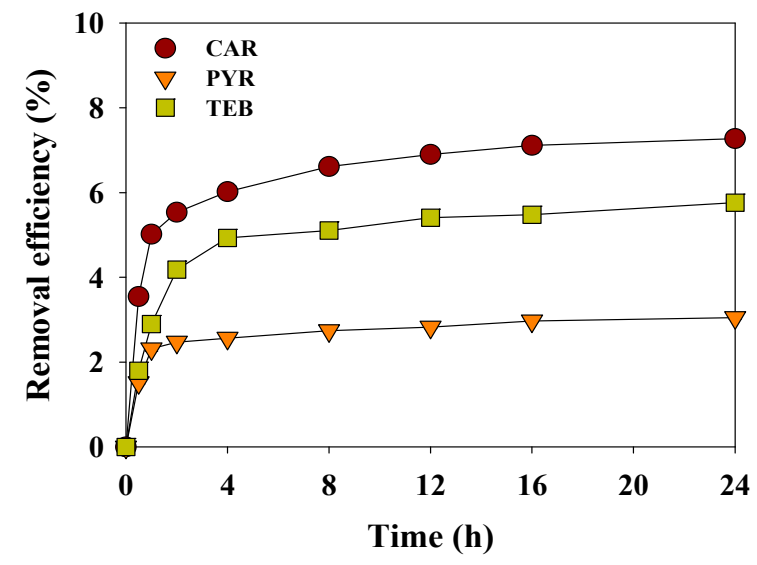

(a)

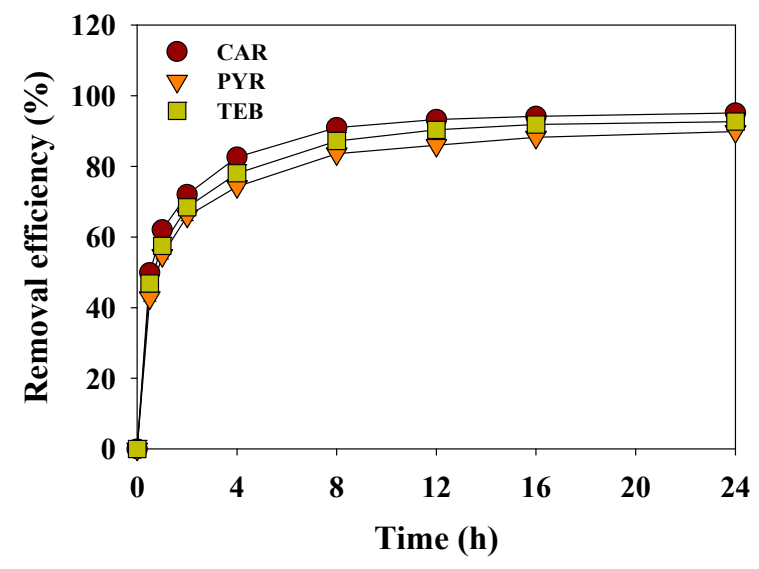

(b)

Figure 5. Adsorption kinetics of the selected fungicides using (a) PSB and (b) PSB OX-A (agitation speed = 150 rpm; absorbent dosage $=50 \mathrm{mg} \mathrm{L}^{-1}$; initial concentration of each fungicide $=10 \mu \mathrm{M}$; temperature $=25^{\circ} \mathrm{C} ; \mathrm{pH}=7.0$ ).

Table 3 presents the adsorption kinetics for CAR, PYR, and TEB when using PSB and PSBOX-A. The pseudo-second-order model $\left(\mathrm{R}^{2}=0.999\right)$ might better explain the adsorption of fungicides when using PSB and PSB ${ }_{O X-A}$ than the pseudo-first-order model 
$\left(\mathrm{R}^{2}=0.882-0.985\right)$. The equilibrium adsorption capacities of the fungicides $\left(Q_{e, \text { exp }}\right)$ on those of PSB $\left(Q_{e, \text { exp }}\right.$ of the PSB $\left.{ }_{\text {OX-A }}=179.7-196.9 \mu \mathrm{mol} \mathrm{g}^{-1}\right)$ were much greater than those of PSB $\left(Q_{e, e x p}\right.$ of the PSB $\left.=6.1-15.1 \mu \mathrm{mol} \mathrm{g}^{-1}\right)$. Furthermore, the $Q_{e, e x p}$ values of CAR, PYR, and TEB toward the PSB and PSB ${ }_{O X X-A}$ demonstrate similar trends as those of the theoretical adsorption capacities $\left(Q_{e, \text { cal }}\right)$ calculated by the pseudo-second-order model $\left(Q_{e, \text { cal }}\right.$ of the PSB $=6.7-15.4 \mu \mathrm{mol} \mathrm{g}^{-1}, Q_{e, \text { cal }}$ of the PSB OX-A $\left.=184.9-202.0 \mu \mathrm{mol} \mathrm{g}^{-1}\right)$. These results suggested that the adsorption of CAR, PYR, and TEB on PSB and PSB $\mathrm{OX-A}$ might be chemisorption [31].

Table 3. Kinetic parameters for the adsorptions of the selected fungicides using PSB and PSB $\mathrm{OX}-\mathrm{A}$ (agitation speed $=150 \mathrm{rpm}$; contact time $=24 \mathrm{~h}$; absorbent dosage $=50 \mathrm{mg} \mathrm{L}^{-1}$; initial concentration of each fungicide $=10 \mu \mathrm{M}$; temperature $=25^{\circ} \mathrm{C}$; $\mathrm{pH}=7.0)$.

\begin{tabular}{|c|c|c|c|c|c|c|c|c|}
\hline \multirow[b]{2}{*}{ Absorbents } & \multirow{2}{*}{ Compounds } & \multirow{2}{*}{$\begin{array}{c}Q_{e, \exp } \\
\left(\mu \mathrm{mol} \mathrm{g}{ }^{-1}\right)\end{array}$} & \multicolumn{3}{|c|}{ Pseudo-Fist-Order } & \multicolumn{3}{|c|}{ Pseudo-Second-Order } \\
\hline & & & $\begin{array}{c}Q_{e, c a l} \\
\left(\mu \mathrm{mol} \mathrm{g}^{-1}\right)\end{array}$ & $\begin{array}{c}k_{1} \\
\left(1 \mathrm{~h}^{-1}\right)\end{array}$ & $R^{2}$ & $\begin{array}{c}Q_{e, c a l} \\
\left(\mu \mathrm{mol} \mathrm{g}^{-1}\right)\end{array}$ & 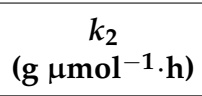 & $R^{2}$ \\
\hline \multirow{3}{*}{ PSB } & CAR & $15.1 \pm 0.1$ & $6.1 \pm 0.3$ & $0.2 \pm 0.04$ & 0.976 & $15.4 \pm 0.1$ & $0.09 \pm 0.01$ & 0.999 \\
\hline & PYR & $6.1 \pm 0.1$ & $2.1 \pm 0.3$ & $0.1 \pm 0.02$ & 0.915 & $6.7 \pm 0.05$ & $0.08 \pm 0.01$ & 0.999 \\
\hline & TEB & $11.6 \pm 0.2$ & $5.4 \pm 0.6$ & $0.1 \pm 0.03$ & 0.882 & $10.1 \pm 0.1$ & $0.2 \pm 0.005$ & 0.999 \\
\hline \multirow{3}{*}{ PSB $\mathrm{OX}-\mathrm{A}$} & CAR & $196.9 \pm 0.2$ & $81.9 \pm 1.1$ & $0.3 \pm 0.03$ & 0.983 & $\begin{array}{c}202.0 \pm \\
0.07\end{array}$ & $0.008 \pm 0.004$ & 0.999 \\
\hline & PYR & $179.7 \pm 0.06$ & $81.4 \pm 1.3$ & $0.2 \pm 0.02$ & 0.982 & $184.9 \pm 1.0$ & $0.007 \pm 0.003$ & 0.999 \\
\hline & TEB & $186.2 \pm 0.2$ & $88.3 \pm 2.2$ & $0.2 \pm 0.05$ & 0.985 & $192.0 \pm 1.6$ & $0.007 \pm 0.002$ & 0.999 \\
\hline
\end{tabular}

\subsection{Adsorption Isotherms of Fungicides}

The adsorption of CAR, PYR, and TEB by PSB and PSB $O$-A were examined by using the Langmuir and Freundlich isotherm models (Figure 6 and Table 4). The adsorption behaviors of CAR, PYR, and TEB with respect to PSB and PSB ${ }_{\mathrm{OX}-\mathrm{A}}$ are better explained by the Langmuir isotherm model $\left(R^{2}=0.996-0.999\right)$ than the Freundlich isotherm model $\left(R^{2}=0.764-0.995\right)$. This indicated that monolayer adsorption played a key role in removing the fungicides from the homogeneous surfaces of PSB and PSB ${ }_{O X-A}$ [32]. The adsorption affinities of CAR, PYR, and TEB to PSB and PSB $\mathrm{OX}-\mathrm{A}$ were evaluated by using the $R_{L}$ values. The $R_{L}$ values, namely (i) $R_{L}>1$ : unfavorable, (ii) $R_{L}=1$ : linear, (iii) $0<R_{L}<1$ : favorable, and (iv) $R_{L}=0$ : irreversible, of the Langmuir isotherm model were used to identify the

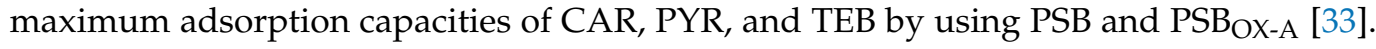
The $R_{L}$ values of PSB and PSB $\mathrm{OX}-\mathrm{A}$ were estimated to be favorable $\left(R_{L}=0.08-0.8\right)$.

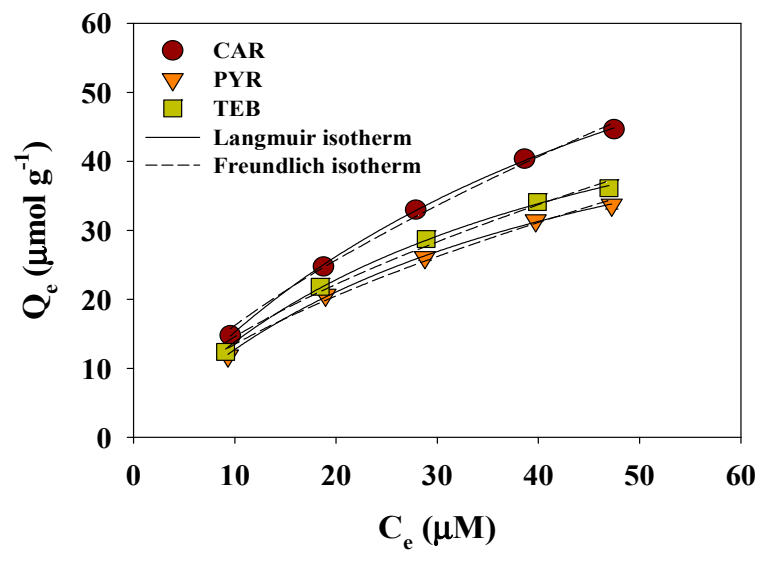

(a)

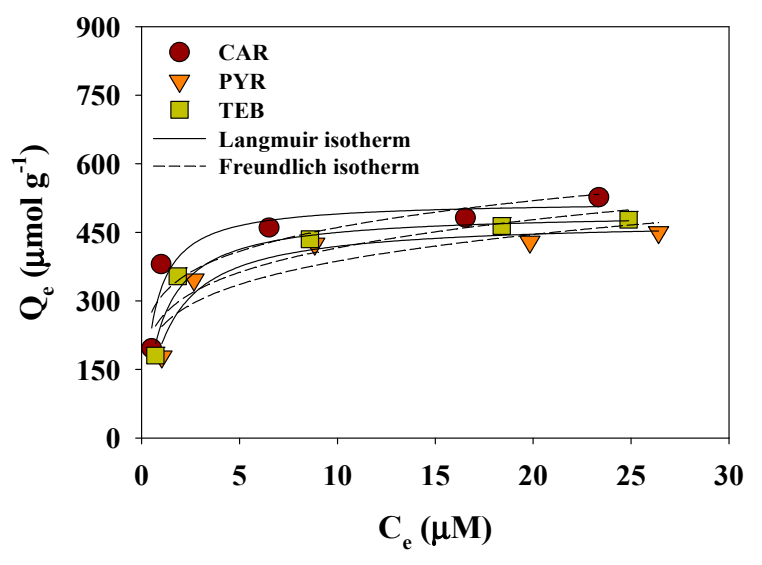

(b)

Figure 6. Adsorption isotherms of fungicides on (a) PSB and (b) PSB $_{\mathrm{OX}-\mathrm{A}}$ (agitation speed = $150 \mathrm{rpm}$; contact time = $24 \mathrm{~h}$; absorbent dosage $=50 \mathrm{mg} \mathrm{L}^{-1}$; initial concentration of each fungicide $=10 \mu \mathrm{M}$; temperature $=25^{\circ} \mathrm{C} ; \mathrm{pH}=7.0$ ). 
Table 4. Isotherm parameters for the adsorptions of fungicides using PSB and PSB OX-A (agitation speed = $150 \mathrm{rpm}$; contact time $=24 \mathrm{~h}$; absorbent dosage $=50 \mathrm{mg} \mathrm{L}^{-1}$; initial concentration of each fungicide $=10 \mu \mathrm{M}$; temperature $=25^{\circ} \mathrm{C} ; \mathrm{pH}=7.0$ ).

\begin{tabular}{|c|c|c|c|c|c|c|c|}
\hline \multirow[b]{2}{*}{ Absorbents } & \multirow[b]{2}{*}{ Compounds } & \multicolumn{3}{|c|}{ Langmuir } & \multicolumn{3}{|c|}{ Freundlich } \\
\hline & & $\begin{array}{c}Q_{\max } \\
\left(\mu \operatorname{mol~} \mathrm{g}^{-1}\right)\end{array}$ & $\begin{array}{c}K_{L} \\
\left(\mathrm{~L} \mu \mathrm{mol}^{-1}\right)\end{array}$ & $R^{2}$ & $n$ & $\begin{array}{c}K_{F} \\
\left(\mu \mathrm{mol}^{1-(1 / n)}\right) \\
\left.\mathrm{L}^{1 / n} g^{-1}\right)\end{array}$ & $R^{2}$ \\
\hline \multirow{3}{*}{ PSB } & CAR & $92.6 \pm 1.3$ & $0.02 \pm 0.004$ & 0.999 & $1.4 \pm 0.03$ & $3.1 \pm 0.03$ & 0.995 \\
\hline & PYR & $61.7 \pm 2.2$ & $0.03 \pm 0.001$ & 0.998 & $1.5 \pm 0.04$ & $2.9 \pm 0.01$ & 0.990 \\
\hline & TEB & $66.7 \pm 0.5$ & $0.03 \pm 0.002$ & 0.996 & $1.5 \pm 0.02$ & $3.0 \pm 0.05$ & 0.988 \\
\hline \multirow{3}{*}{ PSB $\mathrm{OX}-\mathrm{A}$} & CAR & $531.2 \pm 1.9$ & $1.2 \pm 0.1$ & 0.997 & $4.9 \pm 0.07$ & $288.9 \pm 0.7$ & 0.764 \\
\hline & PYR & $467.7 \pm 1.2$ & $0.8 \pm 0.05$ & 0.999 & $3.9 \pm 0.03$ & $214.9 \pm 0.8$ & 0.800 \\
\hline & TEB & $495.1 \pm 2.5$ & $0.9 \pm 0.3$ & 0.999 & $4.1 \pm 0.04$ & $239.1 \pm 0.6$ & 0.826 \\
\hline
\end{tabular}

\subsection{Effects of $\mathrm{pH}$ on Adsorption of Fungicides}

Figure 7 depicts the adsorption behaviors of CAR, PYR, and TEB for PSB and PSB $\mathrm{OX}$-A at three different $\mathrm{pH}$ values $(\mathrm{pH}=3,7$, and 11$)$. The removal efficiencies of CAR $(11.5 \% \rightarrow$ $6.9 \%)$, PYR $(4.8 \% \rightarrow 2.7 \%)$, and TEB $(5.6 \% \rightarrow 3.1 \%)$ by the PSB were negative affected by the increase of $\mathrm{pH}$ values. However, the removal efficiencies of CAR $(97.0 \% \rightarrow 96.6 \%)$ and PYR $(91.0 \% \rightarrow 90.6 \%)$ by the $\mathrm{PSB}_{\mathrm{OX}-\mathrm{A}}$ were not significantly different under the different $\mathrm{pH}$ values. The change in $\mathrm{pH}$ values strongly influenced the removal efficiency of TEB $(94.3 \%$ $\rightarrow 93.2 \%)$ by the PSB $_{\text {OX-A }}$ due to the lower pKa value of TEB $\left(\mathrm{pK}_{\mathrm{a}}=2.01\right)$ compared with the CAR $\left(\mathrm{pK}_{\mathrm{a}}=4.28\right)$ and PYR $\left(\mathrm{pK}_{\mathrm{a}}=3.44\right)$. Moreover, the deprotonated fungicides could promote the electrostatic repulsive interaction between the fungicides and the PSB under the $\mathrm{pH}$ value was higher than their $\mathrm{pK}_{\mathrm{a}}$ values [12]. These observations could explain that the electrostatic interactions between fungicides and absorbents under the different $\mathrm{pH}$ values played a key role in the adsorptions of the CAR, PYR, and TEB using the PSB and PSB $_{\text {OX-A }}$.

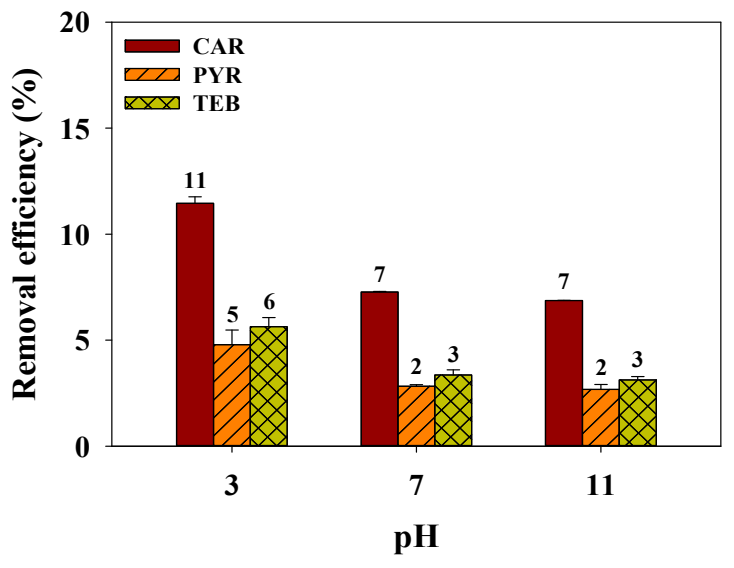

(a)

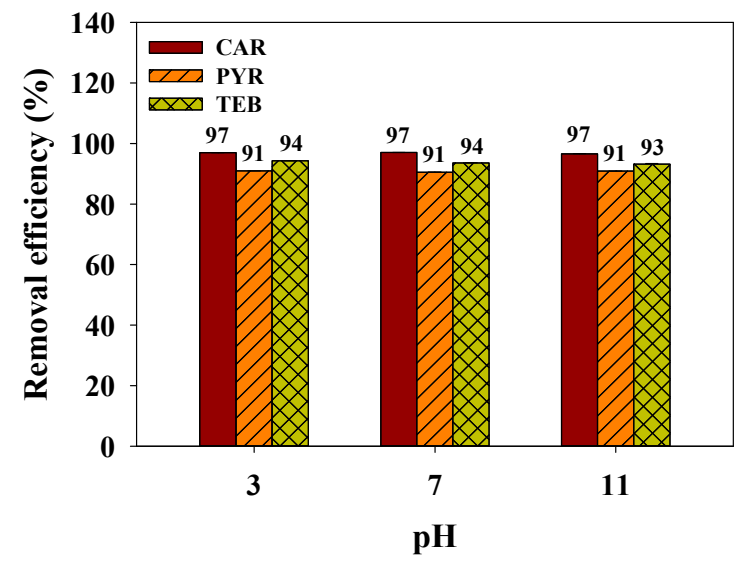

(b)

Figure 7. The effects of the $\mathrm{pH}$ on the adsorption of fungicides by (a) the PSB and (b) $\mathrm{PSB}_{\mathrm{OX}-\mathrm{A}}$ (agitation speed = $150 \mathrm{rpm}$; contact time $=24 \mathrm{~h}$; absorbent dosage $=50 \mathrm{mg} \mathrm{L}^{-1}$; initial concentration of each fungicide $=10 \mu \mathrm{M}$; temperature $=25^{\circ} \mathrm{C}$ )

\subsection{Effects of Temperature and Thermodynamic Studies}

The effects of temperature $\left(15-35^{\circ} \mathrm{C}\right)$ on the adsorption of fungicides using PSB and $\mathrm{PSB}_{\mathrm{OX}-\mathrm{A}}$ are illustrated in Figure 8 . The removal efficiencies of fungicides using PSB $\left(15^{\circ} \mathrm{C}\right.$ : $\mathrm{CAR}=4.8 \pm 0.4 \%, \mathrm{PYR}=1.0 \pm 0.04 \%$, and TEB $=2.8 \pm 0.03 \% ; 25^{\circ} \mathrm{C}: \mathrm{CAR}=7.2 \pm 0.1 \%$, $\mathrm{PYR}=2.3 \pm 0.2 \%$, and TEB $=4.6 \pm 0.1 \% ; 35^{\circ} \mathrm{C}: \mathrm{CAR}=8.9 \pm 0.1 \%, \mathrm{PYR}=3.3 \pm 0.04 \%$, and TEB $=5.6 \pm 0.2 \%)$ and $\mathrm{PSB}_{\mathrm{OX}-\mathrm{A}}\left(15^{\circ} \mathrm{C}: \mathrm{CAR}=94.3 \pm 0.01 \%\right.$, PYR $=88.2 \pm 0.03 \%$, and TEB $=92.8 \pm 0.1 \% ; 25^{\circ} \mathrm{C}: \mathrm{CAR}=94.8 \pm 0.02 \%$, PYR $=90.0 \pm 0.1 \%$, and TEB $=93.8 \pm 0.02 \%$; $35{ }^{\circ} \mathrm{C}: \mathrm{CAR}=95.8 \pm 0.1 \%, \mathrm{PYR}=91.3 \pm 0.1 \%$, and TEB $=94.7 \pm 0.01 \%$ ) increased with 
temperature. A similar result was observed for the removal of herbicides by ground coffee residue biochars [14]. Moreover, the adsorption behaviors of CAR, PYR, and TEB using PSB and $\mathrm{PSB}_{\mathrm{OX}-\mathrm{A}}$ showed the same trends (CAR $>$ TEB $>$ PYR) under different temperature conditions. Table 5 shows the results of the thermodynamic parameters $\left(\Delta G^{\circ}, \Delta H^{\circ}\right.$, and

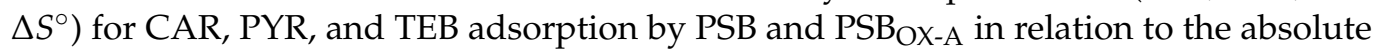
temperatures (288-308 K). The $\Delta G^{\circ}<0$ values indicated that the adsorption process was spontaneous. The $\Delta H^{\circ}>0$ values designated that the adsorption reaction of CAR, PYR, and TEB on PSB and PSB $\mathrm{OX}-\mathrm{A}$ was endothermic [30]. Low $\Delta H^{\circ}$ values $\left(<40 \mathrm{~kJ} \mathrm{~mol}^{-1}\right)$ might be attributed to the physical adsorption [34]. Furthermore, $\Delta S^{\circ}>0$ values showed conducive to adsorption stability due to irreversible adsorption [35].

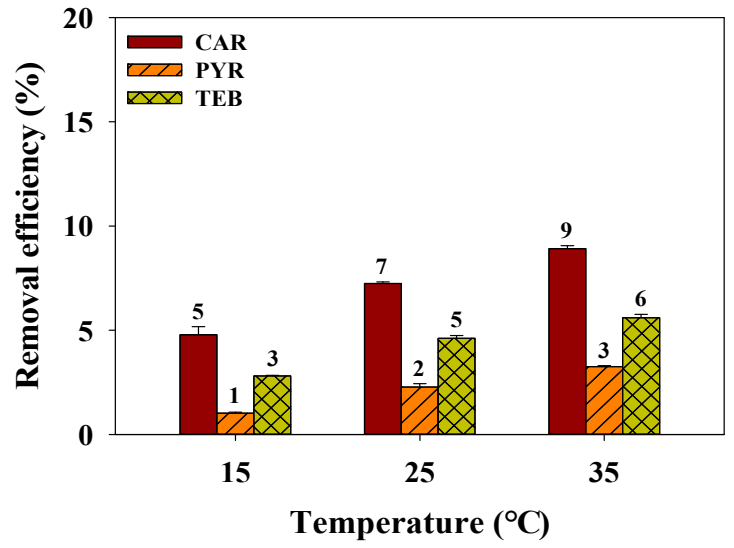

(a)

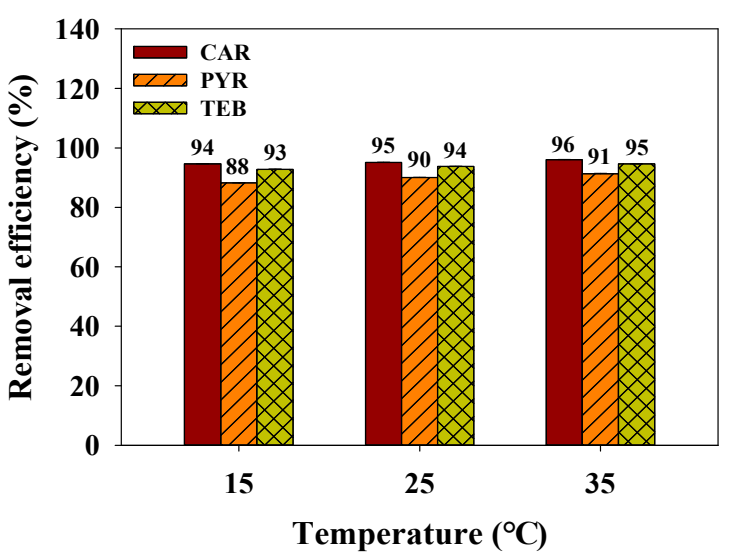

(b)

Figure 8. Effects of temperature on the adsorption of fungicides by (a) the PSB and (b) $\mathrm{PSB}_{\mathrm{OX}-\mathrm{A}}$ (agitation speed = $150 \mathrm{rpm}$; contact time $=24 \mathrm{~h}$; absorbent dosage $=50 \mathrm{mg} \mathrm{L}^{-1}$; initial concentration of each fungicide $\left.=10 \mu \mathrm{M} ; \mathrm{pH}=7.0\right)$.

Table 5. Thermodynamic parameters of fungicides adsorption onto PSB and PSB $\mathrm{OX}-\mathrm{A}$ (agitation speed $=150 \mathrm{rpm}$; contact time $=24 \mathrm{~h}$; absorbent dosage $=50 \mathrm{mg} \mathrm{L}^{-1} ;$ initial concentration of each fungicide $=10 \mu \mathrm{M} ; \mathrm{pH}=7.0$ ).

\begin{tabular}{|c|c|c|c|c|c|}
\hline \multirow[b]{2}{*}{ Adsorbents } & \multirow[b]{2}{*}{ Fungicides } & \multirow{2}{*}{$\begin{array}{c}\text { Temperature } \\
\text { (K) }\end{array}$} & \multicolumn{3}{|c|}{ Thermodynamic Parameters } \\
\hline & & & $\begin{array}{c}\Delta G^{\circ} \\
(\mathrm{kJ} \mathrm{mol}-1)\end{array}$ & $\begin{array}{c}\Delta H^{\circ} \\
\left(\mathrm{kJ} \mathrm{mol}^{-1}\right)\end{array}$ & $\begin{array}{c}\Delta S^{\circ} \\
\left(\mathrm{J} \mathrm{mol}^{-1} \mathrm{~K}\right)\end{array}$ \\
\hline \multirow{9}{*}{ PSB } & \multirow{3}{*}{ CAR } & 288 & $-16.6 \pm 0.4$ & \multirow{3}{*}{$0.003 \pm 0.04$} & \multirow{4}{*}{$0.048 \pm 0.003$} \\
\hline & & 298 & $-18.3 \pm 0.1$ & & \\
\hline & & 308 & $-19.5 \pm 0.1$ & & \\
\hline & \multirow{3}{*}{ PYR } & 288 & $-12.8 \pm 0.1$ & \multirow{3}{*}{$0.002 \pm 0.0003$} & \\
\hline & & 298 & $-15.2 \pm 0.2$ & & \multirow[t]{2}{*}{$0.037 \pm 0.001$} \\
\hline & & 308 & $-16.7 \pm 0.1$ & & \\
\hline & \multirow{3}{*}{ TEB } & 288 & $-15.2 \pm 0.1$ & \multirow{3}{*}{$0.002 \pm 0.0004$} & \multirow{3}{*}{$0.045 \pm 0.005$} \\
\hline & & 298 & $-17.0 \pm 0.2$ & & \\
\hline & & 308 & $-18.1 \pm 0.2$ & & \\
\hline \multirow{9}{*}{$\mathrm{PSB}_{\mathrm{OX}-\mathrm{A}}$} & \multirow{4}{*}{ CAR } & 288 & $-31.9 \pm 0.1$ & \multirow{4}{*}{$0.003 \pm 0.0005$} & \multirow{4}{*}{$0.063 \pm 0.002$} \\
\hline & & 298 & $-33.5 \pm 0.2$ & & \\
\hline & & 308 & $-35.8 \pm 0.3$ & & \\
\hline & & 288 & $-28.7 \pm 0.3$ & & \\
\hline & \multirow[t]{3}{*}{ PYR } & 298 & $-30.1 \pm 0.9$ & \multirow{3}{*}{$0.005 \pm 0.0007$} & \multirow{3}{*}{$0.090 \pm 0.011$} \\
\hline & & 308 & $-31.6 \pm 0.2$ & & \\
\hline & & 288 & $-30.0 \pm 0.9$ & & \\
\hline & \multirow[t]{2}{*}{ TEB } & 298 & $-31.5 \pm 0.2$ & \multirow[t]{2}{*}{$0.005 \pm 0.0006$} & \multirow[t]{2}{*}{$0.096 \pm 0.013$} \\
\hline & & 308 & $-33.0 \pm 0.1$ & & \\
\hline
\end{tabular}




\subsection{Effects of $\mathrm{NaCl}$ and $\mathrm{HA}$ on Adsorption of Fungicides}

The effects of ionic strength $(\mathrm{NaCl}=0-0.1 \mathrm{M})$ on the adsorption of CAR, PYR, and TEB by PSB and PSB $_{O X-A}$ are compared in Figure 9. The removal efficiencies of CAR, $\mathrm{PYR}$, and TEB using PSB and $\mathrm{PSB}_{\mathrm{OX}-\mathrm{A}}$ were progressively improved with increasing ionic strengths (PSB: removal efficiency of CAR $=6.8 \pm 0.07 \% \rightarrow 10.3 \pm 0.2 \%$, removal efficiency of PYR $=2.8 \pm 0.03 \% \rightarrow 7.3 \pm 0.08 \%$, removal efficiency of TEB $=3.5 \pm 0.1 \% \rightarrow 9.3 \pm$ $0.05 \%$; $\mathrm{PSB}_{\mathrm{OX}-\mathrm{A}}$ : removal efficiency of CAR $=97.1 \pm 0.02 \% \rightarrow 98.2 \pm 0.01 \%$, removal efficiency of PYR $=90.5 \pm 0.01 \% \rightarrow 91.6 \pm 0.01 \%$, removal efficiency of TEB $=94.3 \pm$ $0.02 \% \rightarrow 95.6 \pm 0.02 \%)$. These findings reveal that reduced solubility of fungicides with increasing concentrations of $\mathrm{NaCl}$ can support the adsorption capacity of PSB and PSB $\mathrm{OX}-\mathrm{A}$ under different ionic strength conditions (salting-out effect) [36,37].

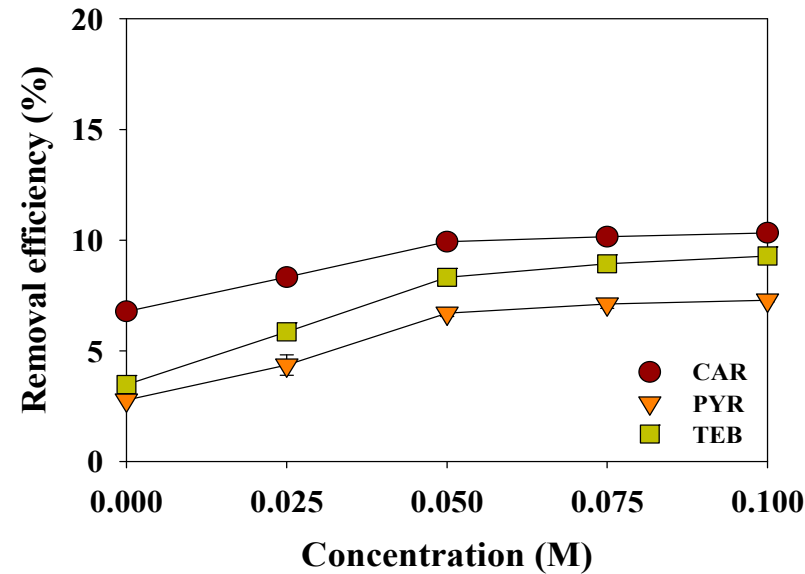

(a)

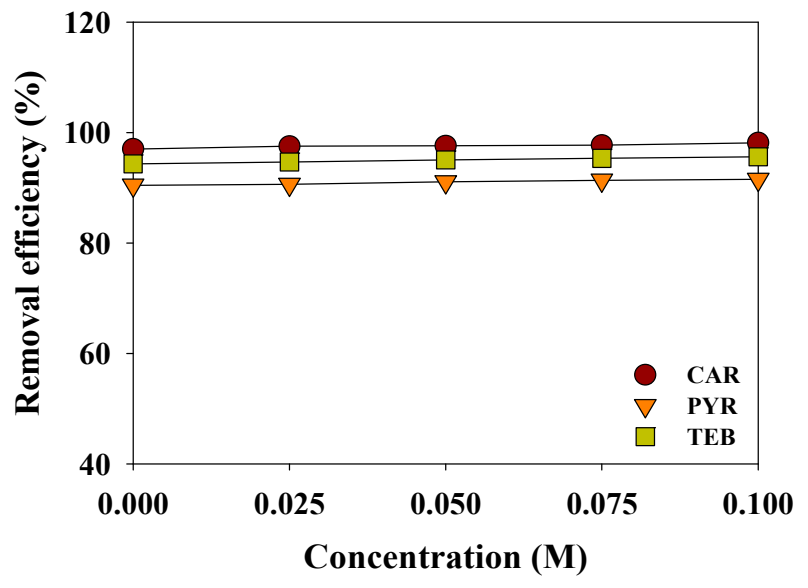

(b)

Figure 9. Effects of $\mathrm{NaCl}$ concentration on the adsorption of fungicides by (a) PSB and (b) PSB $\mathrm{Ox}-\mathrm{A}$ (agitation speed = $150 \mathrm{rpm}$; contact time $=24 \mathrm{~h}$; absorbent dosage $=50 \mathrm{mg} \mathrm{L}^{-1}$; initial concentration of each fungicide $=10 \mu \mathrm{M}$; temperature $=$ $\left.25^{\circ} \mathrm{C} ; \mathrm{pH}=7.0\right)$.

The effects of HA on the adsorption of CAR, PYR, and TEB for PSB and PSB $\mathrm{OX}_{-\mathrm{A}}$ are presented in Figure 10. HA, macromolecular compounds with many reactive functional groups, might scavenge the binding sites generated on PSB and PSB $\mathrm{OX}-\mathrm{A}$. Thus, HA used in the batch experiments could affect the adsorption affinity of fungicides with adsorbents [38]. The removal efficiencies of CAR, PYR, and TEB by PSB are similar to the existence of HA (removal efficiency without HA: CAR $=7.1 \pm 0.07 \%$, PYR $=2.8 \pm 0.09 \%$, and TEB $=4.3 \pm$ $0.3 \%$; removal efficiency with HA: $\mathrm{CAR}=6.8 \pm 0.3 \%, \mathrm{PYR}=2.4 \pm 0.2 \%$, and TEB $=2.8 \pm$ $0.1 \%$ ). The removal efficiencies of CAR, PYR, and TEB using PSB ${ }_{\mathrm{OX}-\mathrm{A}}$ are not significantly affected by the presence of HA (removal efficiency without HA: CAR $=95.2 \pm 0.02 \%$, PYR $=89.7 \pm 0.07 \%$, and TEB $=93.7 \pm 0.02 \%$; removal efficiency with HA: CAR $=93.8 \pm$ $0.3 \%, \mathrm{PYR}=88.9 \pm 0.3 \%$, and TEB $=93.3 \pm 0.07 \%$ ). These observations suggested that the adsorption behavior of CAR, PYR, and TEB by PSB and PSB OX-A $_{\text {-A }}$ were outcompeted by HA adsorption [12]. 


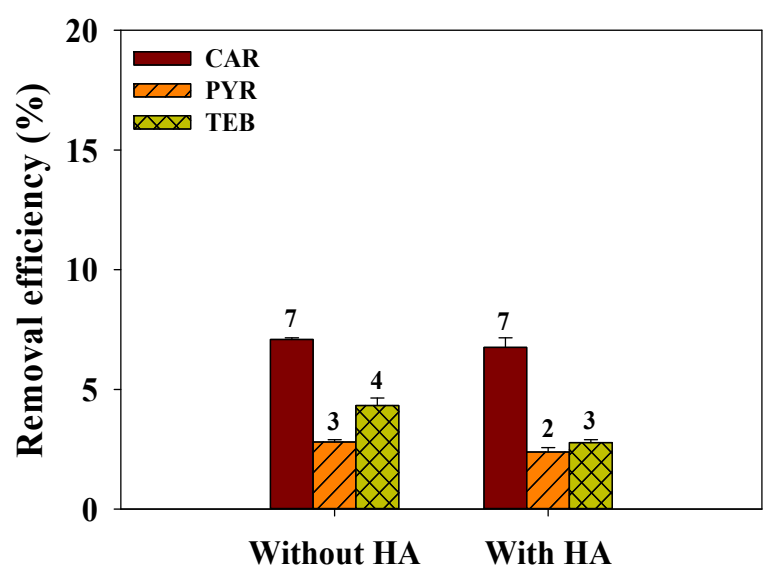

(a)

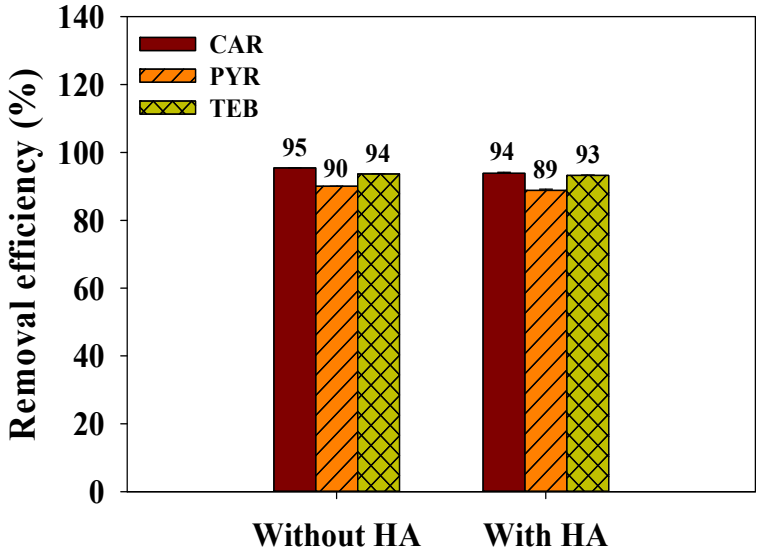

(b)

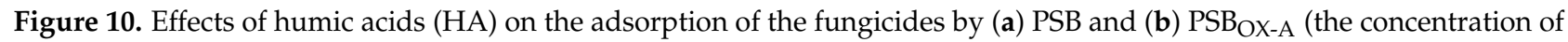
$\mathrm{HA}=5 \mathrm{mg} \mathrm{L}^{-1}$, agitation speed $=150 \mathrm{rpm}$; contact time $=24 \mathrm{~h}$; absorbent dosage $=50 \mathrm{mg} \mathrm{L}^{-1}$; initial concentration of each fungicide $=10 \mu \mathrm{M}$; temperature $=25^{\circ} \mathrm{C} ; \mathrm{pH}=7.0$ ).

\section{Conclusions}

This study examined the effects of successive $\mathrm{KMnO}_{4}$ and $\mathrm{KOH}$ modifications on the physicochemical properties of PSB associated with the adsorption behaviors of CAR, PYR, and TEB. Compared to PSB, PSB $_{\text {OX-A }}$ presented a higher specific surface area $\left(1977.6 \mathrm{~m}^{2} \mathrm{~g}^{-1}\right)$ and total pore volume $\left(0.12 \mathrm{~cm}^{3} \mathrm{~g}^{-1}\right)$. The PSB and PSB $\mathrm{OX}$-A were well fitted with the pseudo-second-order kinetic $\left(R^{2}=0.999\right)$, and the equilibrium adsorption capacities of CAR, PYR, and TEB on PSB OX-A $\left(Q_{e, \text { exp }}=179.7-196.9 \mu \mathrm{mol} \mathrm{g}^{-1}\right)$ were greater than those of PSB $\left(Q_{e, \exp }=6.1-15.1 \mu \mathrm{mol} \mathrm{g}{ }^{-1}\right)$. These findings indicate that chemisorption plays a crucial role in the adsorption of CAR, PYR, and TEB. Moreover, the Langmuir isotherms predominantly governed the removal of fungicides from the homogeneous surfaces of PSB and $\mathrm{PSB}_{\mathrm{OX}-\mathrm{A}}$ (monolayer adsorption, $R^{2}=0.996-0.999$ ). The removal efficiencies of CAR, $\mathrm{PYR}$, and TEB using PSB and $\mathrm{PSB}_{\mathrm{OX}-\mathrm{A}}$ gradually increased with increasing temperature and $\mathrm{NaCl}$ concentration. Although HA could interfere with CAR, PYR, and TEB adsorptions by $\mathrm{PSB}$ and $\mathrm{PSB}_{\mathrm{OX}-\mathrm{A}}$, the removal efficiencies of fungicides by $\mathrm{PSB}_{\mathrm{OX}-\mathrm{A}}(88.9-93.8 \%)$ were higher when compared to PSB (2.4-6.8\%). These results suggest that successive $\mathrm{KMnO}_{4}$ and $\mathrm{KOH}$ modification may be a promising option in improving the adsorption capacities of PSB for removing CAR, PYR, and TEB from a real-scale water treatment plant. Future studies need to provide the information for optimum reuse conditions to regenerate the peanut shell biochars with continuous adsorption ability.

Author Contributions: Conceptualization, Y.-G.L.; methodology, Y.-G.L.; validation, Y.-G.L.; formal analysis, S.K. and C.S.; investigation, J.S. and J.K.; data curation, Y.-G.L.; writing-original draft preparation, Y.-G.L.; writing—review and editing, C.-H.L. and K.C.; supervision, K.C.; funding acquisition, G.-Y.K. All authors have read and agreed to the published version of the manuscript.

Funding: This work was supported by the Technology Development Program (S2979139) funded by the Ministry of SMEs and Startups (MISS, Korea).

Conflicts of Interest: The authors declare no conflict of interest.

\section{References}

1. Gupta, P.K. Toxicity of fungicides. In Veterinary Toxicology, 3rd ed.; Academic Press: Cambridge, MA, USA, 2018; pp. 569-580.

2. Wang, T.; Zhang, Z.; Zhang, H.; Zhong, X.; Liu, Y.; Liao, S.; Yue, X.; Zhou, G. Sorption of carbendazim on activated carbons derived from rape straw and its mechanism. RSC Adv. 2019, 9, 41745-41754. [CrossRef]

3. Merel, S.; Benzing, S.; Gleiser, C.; di Napoli-Davis, G.; Zwiener, C. Occurrence and overlooked sources of the biocide carbendazim in wastewater and surface water. Environ. Pollut. 2018, 239, 512-521. [CrossRef] 
4. Meng, Y.; Zhong, K.; Xiao, J.; Huang, Y.; Wei, Y.; Tang, L.; Chen, S.; Wu, J.; Ma, J.; Cao, Z.; et al. Exposure to pyrimethanil induces developmental toxicity and cardiotoxicity in zebrafish. Chemosphere 2020, 255, 126889. [CrossRef] [PubMed]

5. Li, S.; Wu, Q.; Sun, Q.; Coffin, S.; Gui, W.; Zhu, G. Parental exposure to tebuconazole causes thyroid endocrine disruption in zebrafish and developmental toxicity in offspring. Aquat. Toxicol. 2019, 211, 116-123. [CrossRef]

6. Hgeig, A.; Novaković, M.; Mihajlović, I. Sorption of carbendazim and linuron from aqueous solutions with activated carbon produced from spent coffee grounds: Equilibrium, kinetic and thermodynamic approach. J. Environ. Sci. Health Part B 2019, 54, 226-236. [CrossRef] [PubMed]

7. Ma, X.; Ouyang, F. Adsorption properties of biomass-based activated carbon prepared with spent coffee grounds and pomelo skin by phosphoric acid activation. Appl. Surf. Sci. 2013, 268, 566-570. [CrossRef]

8. Wang, Z.; Zhang, J.; Hu, B.; Yu, J.; Wang, J.; Guo, X. Graphene/ $\mathrm{Fe}_{3} \mathrm{O}_{4}$ nanocomposite for effective removal of ten triazole fungicides from water solution: Tebuconazole as an example for investigation of the adsorption mechanism by experimental and molecular docking study. J. Taiwan Inst. Chem. Eng. 2019, 95, 635-642. [CrossRef]

9. Chen, F.; Song, Z.; Nie, J.; Yu, G.; Li, Z.; Lee, M. Ionic liquid-based carbon nanotube coated magnetic nanoparticles as adsorbent for the magnetic solid phase extraction of triazole fungicides from environmental water. RSC Adv. 2016, 6, 81877-81885. [CrossRef]

10. Yuan, M.; Tong, S.; Zhao, S.; Jia, C.Q. Adsorption of polycyclic aromatic hydrocarbons from water using petroleum coke-derived porous carbon. J. Hazard. Mater. 2010, 181, 1115-1120. [CrossRef] [PubMed]

11. An, Q.; Jiang, Y.-Q.; Nan, H.-Y.; Yu, Y.; Jiang, J.-N. Unraveling sorption of nickel from aqueous solution by KMnO4 and $\mathrm{KOH}$-modified peanut shell biochar: Implicit mechanism. Chemosphere 2019, 214, 846-854. [CrossRef]

12. Shin, J.; Lee, Y.-G.; Lee, S.-H.; Kim, S.; Ochir, D.; Park, Y.; Kim, J.; Chon, K. Single and competitive adsorptions of micropollutants using pristine and alkali-modified biochars from spent coffee grounds. J. Hazard. Mater. 2020, 400, 123102. [CrossRef]

13. Suo, F.; You, X.; Ma, Y.; Li, Y. Rapid removal of triazine pesticides by P doped biochar and the adsorption mechanism. Chemosphere 2019, 235, 918-925. [CrossRef]

14. Lee, Y.-G.; Shin, J.; Kwak, J.; Kim, S.; Son, C.; Cho, K.H.; Chon, K. Effects of NaOH Activation on Adsorptive Removal of Herbicides by Biochars Prepared from Ground Coffee Residues. Energies 2021, 14, 1297. [CrossRef]

15. Zhou, Y.; Liu, X.; Xiang, Y.; Wang, P.; Zhang, J.; Zhang, F.; Wei, J.; Luo, L.; Lei, M.; Tang, L. Modification of biochar derived from sawdust and its application in removal of tetracycline and copper from aqueous solution: Adsorption mechanism and modelling. Bioresour. Technol. 2017, 245, 266-273. [CrossRef]

16. Wilson, K.; Yang, H.; Seo, C.W.; Marshall, W.E. Select metal adsorption by activated carbon made from peanut shells. Bioresour. Technol. 2006, 97, 2266-2270. [CrossRef]

17. Allen, S.J.; Gan, Q.; Matthews, R.; Johnson, P.A. Mass transfer processes in the adsorption of basic dyes by peanut hulls. Ind. Eng. Chem. Res. 2005, 44, 1942-1949. [CrossRef]

18. Johns, M.M.; Marshall, W.E.; Toles, C.A. Agricultural by-products as granular activated carbons for adsorbing dissolved metals and organics. J. Chem. Technol. Biotechnol. 1998, 71, 131-140. [CrossRef]

19. McConvey, I.F.; Woods, D.; Lewis, M.; Gan, Q.; Nancarrow, P. The Importance of Acetonitrile in the Pharmaceutical Industry and Opportunities for its Recovery from Waste. Org. Process Res. Dev. 2012, 16, 612-624. [CrossRef]

20. Fu, Y.; Shen, Y.; Zhang, Z.; Ge, X.; Chen, M. Activated bio-chars derived from rice husk via one- and two-step KOH-catalyzed pyrolysis for phenol adsorption. Sci. Total Environ. 2019, 646, 1567-1577. [CrossRef]

21. Liu, R.; Liu, G.; Yousaf, B.; Abbas, Q. Operating conditions-induced changes in product yield and characteristics during thermal-conversion of peanut shell to biochar in relation to economic analysis. J. Clean. Prod. 2018, 193, 479-490. [CrossRef]

22. Bhainsa, K.C.; D'souza, S. Removal of copper ions by the filamentous fungus, Rhizopus oryzae from aqueous solution. Bioresour. Technol. 2008, 99, 3829-3835. [CrossRef]

23. Gorgievski, M.; Božić, D.; Stanković, V.; Štrbac, N.; Šerbula, S. Kinetics, equilibrium and mechanism of $\mathrm{Cu}^{2+}, \mathrm{Ni}^{2+}$ and $\mathrm{Zn}^{2+}$ ions biosorption using wheat straw. Ecol. Eng. 2013, 58, 113-122. [CrossRef]

24. Hayati, B.; Mahmoodi, N.M. Modification of activated carbon by the alkaline treatment to remove the dyes from wastewater: Mechanism, isotherm and kinetic. Desalination Water Treat. 2012, 47, 322-333. [CrossRef]

25. Li, R.; Wang, Z.; Guo, J.; Li, Y.; Zhang, H.; Zhu, J.; Xie, X. Enhanced adsorption of ciprofloxacin by KOH modified biochar derived from potato stems and leaves. Water Sci. Technol. 2018, 77, 1127-1136. [CrossRef] [PubMed]

26. Zhang, J.; Ma, X.; Yuan, L.; Zhou, D. Comparison of adsorption behavior studies of $\mathrm{Cd}^{2+}$ by vermicompost biochar and $\mathrm{KMnO}_{4}$-modified vermicompost biochar. J. Environ. Manag. 2020, 256, 109959. [CrossRef] [PubMed]

27. Bian, S.; Xu, S.; Yin, Z.; Liu, S.; Li, J.; Xu, S.; Zhang, Y. An Efficient Strategy for Enhancing the Adsorption Capabilities of Biochar via Sequential KMnO4-Promoted Oxidative Pyrolysis and $\mathrm{H}_{2} \mathrm{O}_{2}$ Oxidation. Sustainability 2021, 13, 2641. [CrossRef]

28. Huff, M.D.; Kumar, S.; Lee, J.W. Comparative analysis of pinewood, peanut shell, and bamboo biomass derived biochars produced via hydrothermal conversion and pyrolysis. J. Environ. Manag. 2014, 146, 303-308. [CrossRef]

29. Acemioğlu, B. Removal of a reactive dye using $\mathrm{NaOH}$-activated biochar prepared from peanut shell by pyrolysis process. Int. J. Coal Prep. Util. 2019, 1-23. [CrossRef]

30. Ahmad, M.; Lee, S.S.; Dou, X.; Mohan, D.; Sung, J.-K.; Yang, J.E.; Ok, Y.S. Effects of pyrolysis temperature on soybean stover- and peanut shell-derived biochar properties and TCE adsorption in water. Bioresour. Technol. 2012, 118, 536-544. [CrossRef]

31. Ma, J.; Li, S.; Wu, G.; Arabi, M.; Tan, F.; Guan, Y.; Li, J.; Chen, L. Preparation of magnetic metal-organic frameworks with high binding capacity for removal of two fungicides from aqueous environments. J. Ind. Eng. Chem. 2020, 90, 178-189. [CrossRef] 
32. Kim, E.; Jung, C.; Han, J.; Her, N.; Park, C.M.; Jang, M.; Son, A.; Yoon, Y. Sorptive removal of selected emerging contaminants using biochar in aqueous solution. J. Ind. Eng. Chem. 2016, 36, 364-371. [CrossRef]

33. Shin, J.; Lee, Y.-G.; Kwak, J.; Kim, S.; Lee, S.-H.; Park, Y.; Lee, S.-D.; Chon, K. Adsorption of radioactive strontium by pristine and magnetic biochars derived from spent coffee grounds. J. Environ. Chem. Eng. 2021, 9, 105119. [CrossRef]

34. Fan, S.; Tang, J.; Wang, Y.; Li, H.; Zhang, H.; Tang, J.; Wang, Z.; Li, X. Biochar prepared from co-pyrolysis of municipal sewage sludge and tea waste for the adsorption of methylene blue from aqueous solutions: Kinetics, isotherm, thermodynamic and mechanism. J. Mol. Liq. 2016, 220, 432-441. [CrossRef]

35. Son, C.; An, W.; Lee, G.; Jeong, I.; Lee, Y.-G.; Chon, K. Adsorption Characteristics of Phosphate Ions by Pristine, CaCl 2 and $\mathrm{FeCl}_{3}$-Activated Biochars Originated from Tangerine Peels. Separations 2021, 8, 32. [CrossRef]

36. Xiao, X.; Sheng, G.D.; Qiu, Y. Improved understanding of tributyltin sorption on natural and biochar-amended sediments. Environ. Toxicol. Chem. 2011, 30, 2682-2687. [CrossRef]

37. Xiang, Y.; Xu, Z.; Zhou, Y.; Wei, Y.; Long, X.; He, Y.; Zhi, D.; Yang, J.; Luo, L. A sustainable ferromanganese biochar adsorbent for effective levofloxacin removal from aqueous medium. Chemosphere 2019, 237, 124464. [CrossRef]

38. Cano-Aguilera, I.; Haque, N.; Morrison, G.M.; Aguilera-Alvarado, A.F.; Gutiérrez, M.; Gardea-Torresdey, J.L.; de la Rosa, G. Use of hydride generation-atomic absorption spectrometry to determine the effects of hard ions, iron salts and humic substances on arsenic sorption to sorghum biomass. Microchem. J. 2005, 81, 57-60. [CrossRef] 